\title{
nature
}

\section{Rays of hope in eastern Europe}

Although much of Russia struggles to survive, other former Soviet countries are building new research systems with varying success. A critical need is to avoid western domination of their programmes.

$\mathrm{T}$ en years can be a short time in politics, at least in politics of the dimensions that shook central and eastern Europe in the 1990s. For scientists, much changed literally overnight when communism fell. Yet, one thing was all too clear at a Dresden meeting last week of east and west European scientists, organized by Nature and the Volkswagen Foundation, and sponsored by NATO. This was that there is still a long way to go in replacing the systems of science that were so quickly destroyed.

"Emancipation from ideology is less easy than you'd like to think," Andrei Plesu, rector of the New Europe College in Bucharest, told the audience. The restrictive, centralized, communist system desperately needed reform, but the "traps of the cure" also need to be acknowledged, he argued.

It came as no surprise at the meeting to learn that lack of national money for research has undermined efforts to build internationally competitive science bases in all central and eastern European countries. But Plesu's "traps" are less about money shortages per se than, paradoxically, about the isolation that sudden decentralization brought, as a consequence of an immediate loss of all points of reference, and how this fact conspired to allow eastern science agendas to be set by the west, sometimes inappropriately. Former communist countries tended to accept any form of western sponsorship, pretending that the gift was exactly what they wanted and needed, for fear of being left empty-handed, he said.

The mood of the meeting was cautiously optimistic, the bottom line being that things are clearly better than they were. But speakers referred time and again to the unwitting agenda-setting for the east by the west, which in part results from the same international collaboration and direct-aid programmes that served to save the best science from destruction, and helped build up some islands of excellence. Combined with the introduction of competitive distribution of small national research budgets, and in the absence of strongly defined national priorities, this tended to support the status quo. Thus physics- and chemistry-based disciplines have been disproportionately supported, as these were strengths in communist times. Yet energy and environment research, so visibly necessary in the former communist countries, have failed to develop.

\section{Funding failings}

Dependence on the west during the transition could not have been avoided, and it was also no surprise to learn at the meeting that those doing best from it are the 12 European Union (EU) candidate countries: those being considered for EU membership in the next few years. These countries, which include Poland, Hungary and the Czech Republic, are now participating fully in the fifth Framework programme of research. But this participation requires matching funds which consume most of their small national research budgets, thus compounding the problem of research agendas being set in the west.

What is to be done? The meeting made clear that in the foreseeable future the answer for the non-EU candidate countries lies solely in ensuring continuation of foreign funds, particularly those supporting collaborative projects, and those, provided for example by the
Volkswagen Foundation, for supporting young scientists. For countries such as Russia, the situation for science remains desperate and simple survival is the priority. On average, between a third and a half of the research funds of top-quality Russian research institutions come from foreign sources. The Volkswagen Foundation, one of the largest supporters of science in the central and eastern European countries, is aware of the impact that the impending end of its support programme will have.

For most candidate countries, survival and even growth of science is assured, but governments must now be prepared to invest more robustly in their national programmes, to allow a reasonable level of independence to develop. These countries can now afford it.

\section{New targets}

Some speakers also pointed out that scientists themselves should be proactive in identifying emerging areas of research and positioning themselves in them. Günter Stock, head of research at the German pharmaceutical company Schering, advised scientists from central and eastern European countries to establish themselves in many of the new, and still relatively uncrowded, research areas of the postgenomic era. At least 5,000 new candidate drug targets are likely to be identified from genomic information, more than the pharmaceutical industry wants to handle itself, he said. Validating new targets sometimes requires skills that have declined in the west, such as oldfashioned whole-animal physiology, and it also requires a lot of clinical research.

It is widely appreciated that there are fewer constraints on this type of work - as well as stem-cell research which Stock also advocates - in the east than the west. Pharmaceutical companies are actively searching for such collaborations and Stock said scientists should facilitate matchmaking by advertising themselves, perhaps on the Internet. Would this mean imposing yet another agenda set by the west, this time by the pharmaceutical industry? Perhaps, but there are worse ways to survive, and it would at least allow research to move to the forefront of applied biology.

One example of how scientists can be successfully proactive is in Estonia. Being a small and therefore flexible country, Estonia was able to institute reform of its scientific institutions more efficiently and completely than most. It dissolved its Soviet-style Academy of Sciences early on and merged the academy's institutes with universities, which have been granted full autonomy. In this atmosphere, scientists have found the self-confidence to determine their own research agendas, bottom-up.

The boldest example is perhaps the creation of the Estonian Population Genetics Project, whereby the blood of every Estonian will be DNA profiled, to search for disease-associated genes. Scientists at the University of Tartu are already establishing start-up companies in anticipation of the home-grown resources that are likely to emerge. By demonstrating that "traps of the cure" can be avoided, it exemplifies how universities can build on a phenomenon occurring in many eastern and central European countries: a burgeoning popular interest in higher education. 